Available online on 15.1.2019 at http://ujpr.org
Universal Journal of Pharmaceutical Research
An International Peer Reviewed Journal
Open access to Pharmaceutical research

\title{
ESTIMATION OF ANTI-INFLAMMATORY ACTIVITY AS WELL AS APOPTOTIC ACTIVITY OF ETHANOLIC EXTRACTS OF CROCUS SATIVUS B. Arirudran ${ }^{1}\left(\mathbb{D}\right.$, P. Priyadharshini $^{1} \mathbb{D}$, US Mahadeva Rao ${ }^{2 *}(\mathbb{D}$ \\ ${ }^{1}$ PG Department of Biochemistry, SRM Arts and Science College, Kanchipuram district, Tamilnadu, India. ${ }^{2}$ School of Basic Medical Sciences, Faculty of Medicine, Universiti Sultan Zainal Abidin, Kuala Terengganu, 20400 Malaysia.
}

\section{ABSTRACT}

Objective: Inflammation is a body reaction which embroils cellular and biochemical responses, which is not only symptom for shared diseases but also known to be an initial phase for certain serious Alzheimer's, cancer, heart vascular diseases. In order to overcome these drawbacks, there is an urgent need for nutraceuticals with excellent anti-inflammatory response with minimum side effects. An attempt has been made to evaluate the anti-inflammatory activity along with gene expression analysis on ethanolic extracts of Crocus sativus (CSEE).

Methods: Dried stigmas of $C$. sativus were analyzed for anti-inflammatory activity by macrophage scavenging assay. In this study, the phagocytic activity of the extract was tested on oxidative burst reduction of macrophages. RT-PCR was performed to analyze the anti-apoptotic gene expression during cell death, as a result of the compound treatment on cancer cells.

Results: The CSEE unveiled high phagocytic activity on the oxidative burst reduction, presenting intracellular killing and the enhancement of lysosomal enzyme activity, showing the active degranulation of macrophages.

Conclusion: These findings suggest that $C$. sativus possessed excellent anti-inflammatory as well as apoptotic activities. Hence it was proposed that $C$. sativus could be exploited against oxidative stress, anti-inflammatory, cancer and ageing therapy to justify their use in traditional medicine as a nutraceutical.

Keywords: Anti-inflammatory, Crocus sativus, macrophage, nutraceutical, oxidative stress.

Article Info: Received 3 November 2018; Revised 5 December; Accepted 1 January, Available online 15 January 2019

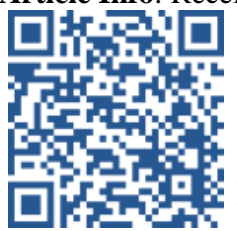

Cite this article-

Arirudran B, Priyadharshini P, Rao USM. Estimation of anti-inflammatory activity as well as apoptotic activity of ethanolic extracts of Crocus sativus. Universal Journal of Pharmaceutical Research 2018; 3(6): 611. DOI: https://doi.org/10.22270/ujpr.v3i6.217

Address for Correspondence

Prof. Dr. US Mahadeva Rao, School of Basic Medical Sciences, Faculty of Medicine, Universiti Sultan Zainal Abidin, Kuala Terengganu, 20400, Malaysia. Phone:+60-1116547654 E-mail: raousm@gmail.com

\section{INTRODUCTION}

Inflammation is a physiological reaction which involves cellular and biochemical responses, which is not only symptom for common diseases but also known to be an early phase for some serious diseases such as alzheimer's disease, cancer, heart vascular diseases etc ${ }^{1}$. Non-steroidal anti-inflammatory drugs like ketoprofen, ibuprofen, aceclofenac, algesia and pyresis are under current clinical usage for the treatment of inflammation ${ }^{2}$, but due to the decrease in production of prostaglandins in tissue ${ }^{3}$ and due to the direct contact of free carboxylic group with the gastric mucosa they were associated with major drawbacks of gastrointestinal disorders like dyspepsia, and gastric ulcers ${ }^{4,5}$. In order to overcome these drawbacks, there is an urgent need for nutraceuticals with excellent antiinflammatory response and minimum side effects. The term "nutraceuticals" combines two words "nutrient" (a nourishing food component) and "pharmaceutical" (a medical drug). The name was coined in 1989 by
Stephen DeFelice, founder and chairman of the Foundation for Innovation in Medicine, an American organization located in Cranford, New Jersey. The philosophy behind nutraceuticals is to focus on prevention, according to the saying by a Greek physician Hippocrates (known as the father of medicine) who said "let food be your medicine". Their role in human nutrition is one of the most important areas of investigation, with wide-ranging implications for consumers, health-care providers, regulators, food producers and distributors. Nutraceuticals are increasingly being used as nutritional supplements in treatment of diseases. Due to the plant origin of these supplements they are considered safe for human consumption. However, the levels of the active substance consumed vary when taken as a whole food, as compared to a nutritional supplement ${ }^{6,7}$. Very few studies have reported on long-term effects of nutrition supplements in humans. Among the nutraceuticals, $C$. sativus is an important crop cultivated as the source of 
its spice for at least 3,500 years. Dried stigmas of saffron flowers compose the most expensive spice which has been valuable since ancient times for its odoriferous, coloring and its medicinal properties ${ }^{8}$. Saffron has been also used as a drug to treat various human health conditions such as coughs, stomach disorders, colic, insomnia, chronic uterine haemorrhage, femine disorder, scarlet fever, smallpox, colds, asthma and cardiovascular disorders ${ }^{9-11}$. Earlier reports say that extractive of saffron shows antitumor effect against different malignant cells ${ }^{12}$ and different tumors as well as cancers in ancient time ${ }^{13}$.The present study is focused to evaluate the anti-inflammatory activity along with apoptotic activity of ethanolic extracts of $C$. sativus (CSEE).

\section{MATERIALS AND METHODS \\ Chemical}

Nitrobluetetrazolium dye, Dimethysulfoxide, Ethanol and all other chemicals and solvents were purchased from Sigma Chemical Co, St. Louis, MO, USA.

Sample collection:

Fresh stigma of $C$. sativus samples were purchased commercially from Nilgiris. Sample was authenticated based on organoleptic, macroscopic examination (PARC/2012/1254) and certified by Dr. P. Jayaraman, Director "National institute of Herbal Science and Plant Anatomy Research Centre" (PARC), West Tambaram, Chennai, Tamilnadu, India.

\section{Preparation of $\boldsymbol{C S E E}$}

The CSEE was prepared as described by the standard method $^{14}$. Ten grams of $C$. sativus dried stigma was coarsely powdered and weighed. The dried powder was soaked with ethanol for $48 \mathrm{hr}$ with intermediate shaking separately. At the end of the extraction, it was passed through Whatman filter paper No.1 (Whatman Ltd., England). Then the filtrate was concentrated by distillation over boiling water bath and the last traces of solvent were removed under vacuum. The yield of the extract was calculated $(1.0443 \mathrm{~g})$, stored in dry sterile container and used for further study.

\section{Macrophage scavenging assay}

Nitrobluetetrazolium dye reduction assay was carried out for macrophage scavenging assay ${ }^{15}$. Briefly, $20 \mu 1$ of the macrophage suspension and $40 \mu 1$ of Roswell park memorial institute medium (RPMI) were added in a flat bottom 96-well plate. Twenty micro liter of the solution containing the CSEE dissolved in $0.1 \%$ Dimethysulfoxide (DMSO) in phosphate buffer saline solution was added in each well at final extract concentrations of $10 \mu \mathrm{g} / \mathrm{ml}, 100 \mu \mathrm{g} / \mathrm{ml}, 500 \mu \mathrm{g} / \mathrm{ml}$ and $1000 \mu \mathrm{g} / \mathrm{ml}$. The $0.1 \%$ DMSO in phosphate buffer alone used as a control. After incubation for $24 \mathrm{hr}$ at $37^{\circ} \mathrm{C}$ in $5 \% \mathrm{CO}_{2}$ humidified atmosphere, $20 \mu \mathrm{l}$ of the heated inactivated yeast (Saccharomyces cerevisiae) suspension $\left(5 \times 10^{7}\right.$ particles/ml $)$ and $20 \mu 1$ of Nitrobluetetrazolium solution in phosphate buffer $(1.5 \mathrm{mg} / \mathrm{ml})$ were added and the mixture was further incubated under the same conditions. After incubation for $60 \mathrm{~min}$, the adherent macrophages were rinsed vigorously with RPMI medium and washed for four times with $200 \mathrm{ml}$ methanol. After air-dried, $120 \mu \mathrm{l}$ of $2 \mathrm{M} \mathrm{KOH}$ and $140 \mu \mathrm{l}$ of DMSO were added. The absorbance was measured at $570 \mathrm{~nm}$ by a well reader (Biorad Plate reader) and the percentage of NBT reduction was calculated by the following equation.

$$
\mathrm{NBT} \text { reduction }(96)=\frac{\text { OD sample }- \text { OD negative control }}{\text { OD negative control }} \mathrm{X100}
$$

The $\mathrm{EC}_{50}$ value represents the effective concentration required for $50 \%$ enhancement of oxidative burst reduction activity.

\section{RT-PCR}

RT-PCR was performed to analyze the gene expression during cell death, as a result of the compound treatment on cancer cells. Cells were harvested after treatment with active fraction. Total RNA was separated and cDNA was synthesized according to the manufacturer's protocol (Sigma Aldrich, USA). Using this cDNA as template, PCR was performed with Tnf and GAPDH gene specific primers.

\section{Total RNA isolation}

Total RNA from cell lines was separated using ONE STEP-RNA solution (phenol and guanidine isothiocyanate). It is a ready to be used reagent for the isolation of total RNA from cells and tissues. The reagent, mono-phasic solution of phenol and guanidine isothiocyanate, represents an improvement to the single step RNA isolation method developed by Chomczynski and $\mathrm{Sacchi}^{16}$. In order to decrease the possibility of RNA degradation during the procedure, all glassware and plastic ware were treated by incubating them overnight in $0.01 \%$ DEPC water (RNase-free) to decrease or reduce the risk of RNA begin depredated by $\mathrm{RNase}^{17}$. After incubation, all of the materials used for isolation were autoclaved and dried in the oven. Approximately $5-10 \times 10^{6}$ cultured cells were taken to ensure for RNA isolation. Cells were pelleted by centrifugation at $1000 \mathrm{rpm}$, 5minutes and $1 \mathrm{ml}$ of ONE STEP-RNA reagent was added. Cell lysis was performed by repeated pipetting. Homogenized samples were incubated at 15 to $30^{\circ} \mathrm{C}$ for $5 \mathrm{~min}$ to allow the complete dissociation of nucleoprotein complexes; $0.2 \mathrm{ml}$ of chloroform per $1 \mathrm{ml}$ of $\mathrm{ONE}$ STEP-RNA reagent to the sample. Tubes were shaken vigorously by hand for $15 \mathrm{sec}$ and incubated at 15 to $30^{\circ} \mathrm{C}$ for about 2 to $3 \mathrm{~min}$ and then the samples were centrifuged at $12,000 \mathrm{rpm}$ for $15 \mathrm{~min}$ at 2 to $8^{\circ} \mathrm{C}$. The mixture separated into two phase, lower phenolchloroform inter-phase of cloudy white and upper colorless aqueous phase.

Table 1: Sequence of the primer used in the RTPCR.

\begin{tabular}{ll}
\hline Tnf F & 5' ATGATGGATCTTGAGAGTCAG 3' \\
\hline Tnf R & 5' TCATAAAGCAAACACCCCAAAGAA 3' \\
\hline GAPDH & 5`TCCCATCACCATCTTCCA 3` \\
Forward & \\
\hline GAPDH & 5`CATCACGCCACAGTTTCC 3` \\
Reverse & \\
\hline
\end{tabular}

The RNA remains exclusively in $60 \%$ volume of upper aqueous phase of ONE STEP-RNA reagent used for homogenization. RNA was precipitated from the aqueous phase by mixing it with isopropyl alcohol. Samples were incubated at 15 to $30^{\circ} \mathrm{C}$ for $10 \mathrm{~min}$ and centrifuged at $12,000 \mathrm{rpm}$ for $10 \mathrm{~min}$ at 2 to $8^{\circ} \mathrm{C}$. The 
RNA precipitate, often invisible before centrifugation, supernatant was removed and the gel-like RNA pellet at the bottom was washed once with $75 \%$ ethanol by centrifuging at $7,500 \mathrm{rpm}$ for $5 \mathrm{~min}$ at 2 to $8^{\circ} \mathrm{C}$. RNA pellet was dried by vacuum-dry for 5 to $10 \mathrm{~min}$ and finally dissolved in DEPC treated water and stored in $20^{\circ} \mathrm{C}$

\section{cDNA preparation}

After RNA isolation, RNA was immediately reverse transcribed with Easy Script Plus ${ }^{\mathrm{TM}}$ Reverse Transcriptase. For RT-PCR, $1-2 \mu \mathrm{g}$ of RNA was used corresponding to $1-10 \mu \mathrm{l}$ of total RNA isolate. RNA isolated from fresh tissue samples was reverse transcribed, where oligo-dT was used as a primer, into a $1.5 \mathrm{ml}$ eppendorf PCR tube, $1-2 \mu \mathrm{g}$ of RNA, $2 \mu \mathrm{l}$ of oligo-dT (stock was $10 \mu \mathrm{M}$ ) was added and the total volume was made up to $12.5 \mu 1$ with $\mathrm{DEPC}$ treated water. The tube was incubated at $65^{\circ} \mathrm{C}$ for $5 \mathrm{~min}$ and chilled on ice. Then, $4 \mu \mathrm{l}$ of $5 \mathrm{X}$ reverse transcriptase buffer (final concentration $1 \mathrm{X}$ ), $2 \mu \mathrm{l}$ of $2 \mathrm{mMdNTP}$ mix (final concentration $0.2 \mathrm{mM}$ ) and $0.5 \mu \mathrm{l}$ of RNase inhibitor $(40 \mathrm{U} / \mu \mathrm{l})$ were added in the indicated order. After incubating at $42^{\circ} \mathrm{C}$ for $5 \mathrm{~min}, 1 \mu \mathrm{l}$ of Easy Script Reverse Transcriptase $(200 \mathrm{U} / \mu \mathrm{l})$ was added. The reaction was carried out at $42^{\circ} \mathrm{C}$ for $50 \mathrm{~min}$. Finally, the tube was heated up to $70^{\circ} \mathrm{C}$ for $10 \mathrm{~min}$ and chilled on ice. The samples were stored at $-20^{\circ} \mathrm{C}$ until further use.

Table 2: PCR reaction setup for GAPDH and Tnf genes.

\begin{tabular}{llcc}
\hline & \multicolumn{1}{c}{$\begin{array}{c}\text { Stock } \\
\text { Concentration }\end{array}$} & Final Concentration & $\begin{array}{c}\text { Final Volume (for } \\
\mathbf{2 0 \mu l} \text { ) }\end{array}$ \\
\hline Mili Q Water & - & - & $11.4 \mu \mathrm{l}$ \\
Taq Buffer (with $\mathrm{MgCl}_{2}$ ) & $10 \mathrm{X}$ & $1 \mathrm{X}$ & $2 \mu \mathrm{l}$ \\
$\mathrm{dNTPs}$ & $2 \mathrm{mM}$ & $0.2 \mathrm{mM}$ & $2 \mu \mathrm{l}$ \\
$\mathrm{MgCl}_{2}$ & $25 \mathrm{mM}$ & $2.5 \mathrm{mM}$ & $2 \mu 1$ \\
Primer-Forward & $3 \mathrm{nM}$ & $0.3 \mu \mathrm{M}$ & $0.2 \mu \mathrm{l}$ \\
Primer-Reverse & $3 \mathrm{M}$ & $0.3 \mu \mathrm{M}$ & $0.2 \mu \mathrm{l}$ \\
Template cDNA & - & $10 \%$ of the reaction & $2 \mu \mathrm{l}$ \\
Taq Polymerase & $5 \mathrm{U} / \mu \mathrm{l}$ & $1 \mathrm{U}$ & $0.2 \mu \mathrm{l}$ \\
\hline
\end{tabular}

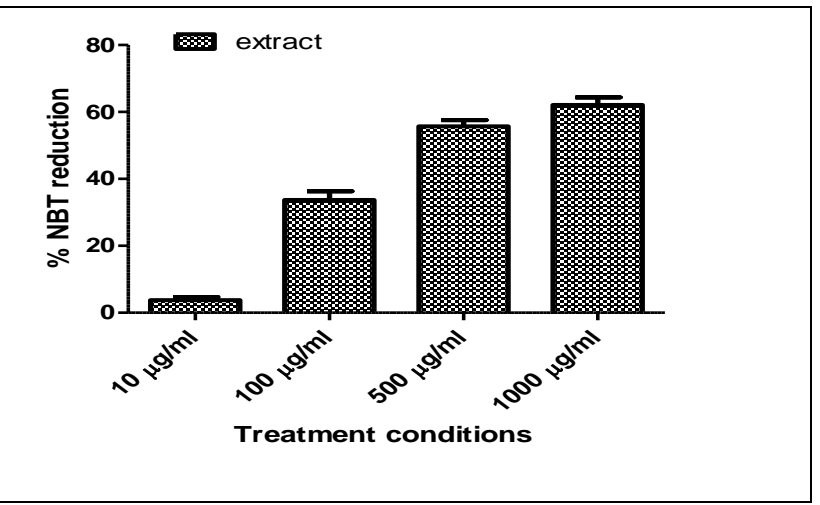

Figure 1: Anti-inflammatory activity for $C$. sativus ethanolic extract.

\section{PCR}

The cDNA obtained was amplified by PCR. Gene specific PCR was used to amplify Tnf. A constitutively expressed gene, namely GAPDH was selected in order to assess the quality of PCR. The primers for the study were purchased from Eurofins Genomics India Pvt Ltd., Bangalore, India. Anti-apoptotic gene expressions were studied using primers intF and intR primers (Table 1, Table 2 and Table 3). Amplification was carried out in a $20 \mu \mathrm{l}$ volume containing $0.3 \mu \mathrm{M}$ of each primer (Eurofins, India), $0.2 \mathrm{mM}$ deoxy nucleotide triphosphates (dATP, dCTP, dGTP and dTTP) (Biotools, Spain), 100ng of template DNA sample and $1 \mathrm{U}$ of Prime Taq DNA polymerase (Genetbio, Korea). The reaction tubes were subjected for thermal cycling reactions consisted of an initial denaturation (3min at $94^{\circ} \mathrm{C}$ ) followed by 32 cycles of denaturation (30 sec at $94^{\circ} \mathrm{C}$ ), annealing $\left(1 \mathrm{~min}\right.$ at $\left.49^{\circ} \mathrm{C}\right)$ and extension $(1 \mathrm{~min}$ $20 \mathrm{sec}$ at $\left.72^{\circ} \mathrm{C}\right)$, with a final extension $\left(7 \mathrm{~min}\right.$ at $\left.72^{\circ} \mathrm{C}\right)$. The procedure was repeated for GAPDH gene. PCR products were visualized using $1.5 \%$ agarose gel stained with $\mathrm{EtBr}(20 \mathrm{mg} / \mathrm{ml})$. The molecular weight of the bands was estimated using $1 \mathrm{~Kb}$ DNA Ladder as reference.

\section{Agarose Gel Electrophoresis of PCR Products}

In a total volume of $25 \mathrm{ml}, 1.5 \%$ agarose and $1 \mathrm{X}$ TAE buffer were prepared and poured onto a gel tray. The PCR product was mixed with the loading dye. The mixture was loaded to each well along with $1 \mathrm{~kb}$ ladder as a reference. The gel was run at $50 \mathrm{~V}$ for $90 \mathrm{~min}$ and visualized.

\section{Expression folds calculation}

Expression ratio was derived by analyzing the gel photos in software-Image $\mathbf{J}$ (Java based image processing). Expression ratio was obtained using the formula:

$$
\text { Target gene }=\frac{\text { gene expression }}{\text { internal control }} \text { X100 }
$$

\section{RESULTS AND DISCUSSION}

In this study, the phagocytic activity of the CSEE was tested on oxidative burst reduction of macrophages. The Figure 1 shows that CSEE enhanced the NBT reduction at $10,100,500$ and $1000 \mu \mathrm{g} / \mathrm{ml}$ by $5 \%(p<$ 
$0.01), 35 \%(p<0.01), 55 \%(p<0.01)$ and $65 \%(p<$ $0.01)$ respectively. The higher reduction in NBT assay represented higher activity of the oxidase enzyme reflecting the stimulation of phagocytes in proportion to the foreign particles ingested ${ }^{15}$. CSEE exhibited high phagocytic activity on the oxidative burst reduction, presenting intracellular killing and the enhancement of lysosomal enzyme activity, showing the active degranulation of macrophages. The maximum phagocytic activity of the extract on the NBT dye reduction was found and the \% of NBT dye reduction was found to be $1000 \mu \mathrm{g}$ of $C S E E$, with an $\mathrm{EC}_{50}$ value of $150 \mathrm{mg} / \mathrm{ml}$.

Table 3: PCR reaction conditions for GAPDH and Tnf genes.

\begin{tabular}{lll}
\hline & Tnf & GAPDH \\
\hline Initial denaturation & $94^{\circ} \mathrm{C}$ for $2 \mathrm{~min}$ & $94^{\circ} \mathrm{C}$ for $2 \mathrm{~min}$ \\
Denaturation & $94^{\circ} \mathrm{C}$ for $30 \mathrm{sec}$ & $94^{\circ} \mathrm{C}$ for $30 \mathrm{sec}$ \\
Annealing & $56^{\circ} \mathrm{C}$ for $1 \mathrm{~min}$ & $53^{\circ} \mathrm{C}$ for $1 \mathrm{~min}$ \\
Extension & $72^{\circ} \mathrm{C}$ for $1 \mathrm{~min} 20 \mathrm{sec}$ & $72^{\circ} \mathrm{C}$ for $1 \mathrm{~min} 20 \mathrm{sec}$ \\
Final extension & $72^{\circ} \mathrm{C}$ for $7 \mathrm{~min}$ & $72^{\circ} \mathrm{C}$ for $7 \mathrm{~min}$ \\
Hold & $4^{\circ} \mathrm{C}$ & $4^{\circ} \mathrm{C}$ \\
Total number of cycles & 32 & 32 \\
\hline
\end{tabular}

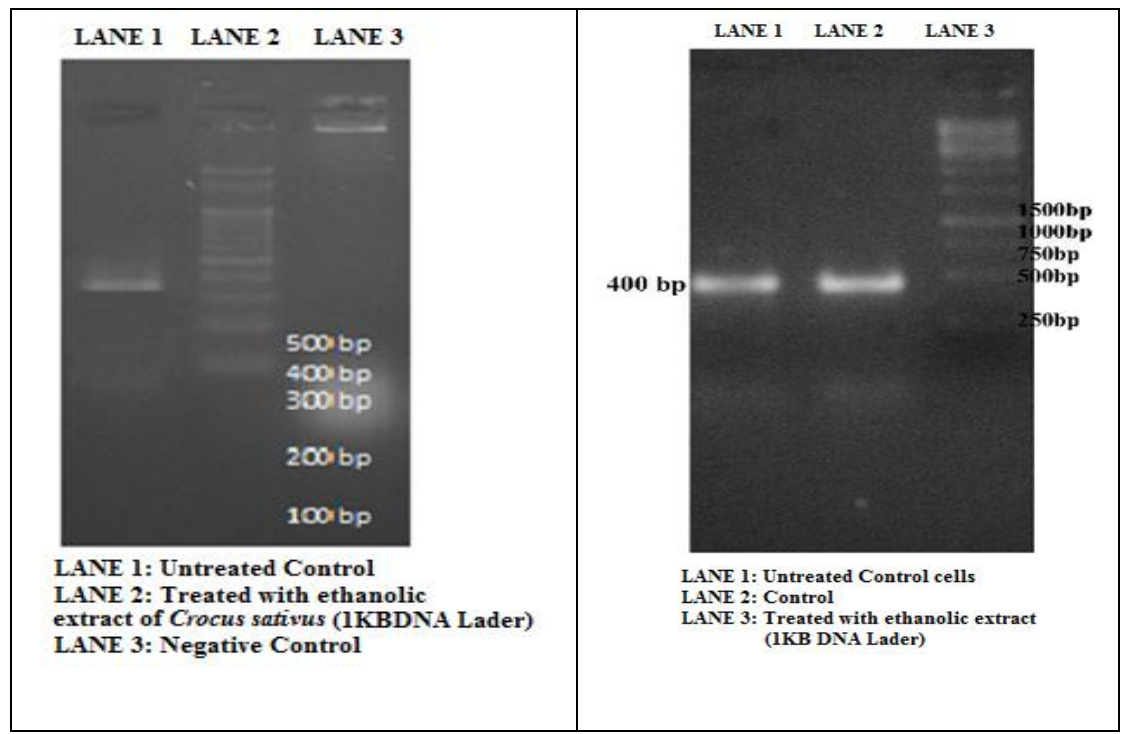

\section{Plate 1}

Plate 2

Figure 2: Plate 1: Expression of Tnf gene, Plate 2: Expression of GAPDH gene.

Crocins, Crocus glycosides, exhibited an antiinflammatory effect in some models of inflammation ${ }^{17}$. Flavonoids such as rutin, quercetin, luteolin, hesperidin and bioflavonoid produced significant antinociceptive and anti-inflammatory activities ${ }^{19-21}$. Flavonoids, tannins, anthocyanins, alkaloids and saponins exhibited antinociceptive effects in chemical pain test as well as acute and chronic anti-inflammatory activity ${ }^{22-23}$. It was reported that tannins has an important role in antinociceptive and anti-inflammatory activities ${ }^{24}$. Phenolic compounds have been shown to possess antioxidant activity based on their (hydroxyl group) donation to free radicals. Moreover, phenolic compounds also possess a wide spectrum of biological activities such as antimutagenic, anticarcinogenic, antiinflammation, anti-allergic, as well as the ability to modify gene expression ${ }^{25-32}$. The authors have had phytochemical study in CSEE and reported that $C$. sativus extract has a rich amount of secondary metabolites like carbohydrates, tannins, saponins, flavonoids, alkaloids, quinones, cardiac glycosides, phenols, coumarins, phyto steroids, anthroquinones ${ }^{33}$. The anti-apoptotic activity related gene expression study results were well aligned with other researcher's findings with different extracts (Musa paradisiaca, Vernoniaamygdalina, Melastomamalabathricum, Persea americana, Monopterusalbus and Channa straitus extracts) as well as secondary metabolites (syringin and scopoletin) ${ }^{34-40}$. Henceforth, these findings advocated that, the phagocytic mediated to macrophage-lymphocyte defense system may be due to the presence of some secondary metabolic active principle compounds present in the CSEE and it is responsible for intracellular killing more than degranulation. This property of $C$. sativus may be a safe and effective choice in the treatment of antiinflammatory disorders. In future, studies should be carried out to pinpoint the mechanism of respective phytochemical both in an animal model and cell lines to exploit the medicinal potential of $C$. sativus.

In the present study the plate 1 and 2 displayed that the RT-PCR was made with Tnf and GAPDH gene specific primers to amplify. In the plate 1 , Tnf gene was expressed in $1 \mathrm{~KB}$ ladder of about $500 \mathrm{bp}$ was observed, in the photographic plate 2 and GAPDH gene was expressed in $1 \mathrm{~KB}$ ladder of about 400bp.

In this model, CSEE caused the suppression and subsequent expression of mRNA for tumor necrosis 
factor, interleukin. It has been demonstrated that CSEE possesses anti-apoptotic effects on non-cancerous cells which incorporate out it into a model showing a possible mechanism for the anti-cancer effect of saffron by promoting apoptosis, inhibiting cell proliferation and blocking inflammation in carcinomas by Tnf expressions. Tumour necrosis factor Tnf is a cytokine that has a wide variety of functions. It can cause cytosis of certain tumor cell lines; it is involved in the induction of cachexia; it is a potent pyrogen, causing fever by direct action or by stimulation of interleukin-1 secretion; it can stimulate cell proliferation induced cell differentiation under certain conditions. These findings indicate that saffron provides an anticancer protective effect by promoting cell death apoptosis and inhibiting proliferation of cancerous cells and blocking inflammation.

\section{CONCLUSION}

In supposition, these preliminary findings indicated that $C$. sativus can be a potential source of natural immune stimulator as well as an antioxidant agent. In addition, CSEE (Saffron stigma and petal) exhibit antinociceptive, anti-inflammatory activity, along with potential free radical scavenger and act as an important tool in cancer prevention. Further studies are warranted to isolate the active constituent from $C$. sativus for herbal preparations against oxidative stress, inflammation, cancer, ageing etc, and justifying their use in traditional medicine.

\section{ACKNOWLEDGEMENTS}

The authors would like to thankful to Mrs. Florida Tilton and Staff members of Biozone research technologies Lab, Chennai, India for providing laboratory facilities and technical assistance.

\section{AUTHOR'S CONTRIBUTION}

The manuscript was carried out, written, and approved in collaboration with all authors.

\section{CONFLICT OF INTEREST}

No conflict of interest associated with this work.

\section{REFERENCES}

1. Ingale $\mathrm{N}$, Maddi V, Palkar M et al., "Synthesis and evaluation of anti-inflammatory and analgesic activity of 3[(5-substituted-1,3,4-oxadiazol-2-yl-thio)acetyl]-2Hchromen-2-ones. Med Chem Res 2012; 21(1): 16-26. https://doi.org/10.1007/s00044-016-1641-8

2. Rigas B. The use of nitric oxide-donating nonsteroidal antiinflammatory drugs in the chemoprevention of colorectal neoplasia. Current Opinion Gastr 2007; 23(1): 55-59. https://doi.org/10.1097/MOG.0b013e32801145b0

3. Venerito M, Wex T, Malfertheiner P. Nonsteroidal antiinflammatory drug-induced gastroduodenal bleeding: risk factors and prevention strategies. Pharmaceuticals 2010; 3(7): 2225-2237. https://doi.org/10.3390/ph3072225

4. Lanas A, García-Rodríguez LA, Arroyo MT, et al. Effect of antisecretory drugs and nitrates on the risk of ulcer bleeding associated with nonsteroidal anti-inflammatory drugs, antiplatelet agents, and anticoagulants. The American J Gastr 2007; 102 (3): 507-515. https://doi.org/10.1111/j.1572-0241.2006.01062.x

5. Prakash S, Gupta BN, Moorthy NSH. Synthesis and physicochemical characterization of mutual prodrug of indomethacin. Trends in Applied Sci Res 2007; 2 (2): 165169. https://doi.org/10.3923/tasr.2007.165.169

6. Egert S, Rimbach G. Which sources of flavonoids: complex diets or dietary supplements?. Adv Nutrition 2011; 2 (1); 814. https://doi.org/10.3945/an.110.000026

7. Kyselova. Toxicological aspects of the use of phenolic compounds in disease prevention. Interdisciplinary Toxicol 2011; 4(4): 173-183. https://doi.org/10.2478/v10102-011-0027-5

8. Plessner O, Negbi M., Ziv M, Basker D. Effects of temperature on the flowering of the saffron crocus (Crocus sativus L.): Induction of hysteranthy. Israel J Bot 1989; 38: 1-7. https://doi.org/10.1016/j.scienta.2004.06.005

9. Giaccio M. Components and features of saffron. Proceedings of the International Conference on Saffron, (ICS'90), Italy. 1990; 135-148. https://doi.org/10.1111/jocd.13284

10. Winterhalter P, Straubinger M. Saffron-renewed interest in an ancient spice. Food Rev Int 2000; 16: 39-59. https://doi.org/10.1081/FRI-100100281

11. Abdullaev F. Crocus sativus against cancer. Arch Med Res 2003; 34: 354-354. https://doi.org/10.1016/j.jnim.2015.12.332

12. Abdulnabi AA, Emhemed AH, Hussein GD, Biacs PA. Determination of antioxidant vitamin in tomatoes. Food Chem 1997; 60: 207-212. https://doi.org/10.1016/S0308-8146(96)00321-4

13. Himeno H, Sano K. Synthesis of crocin, Picrocrocin and safranal by saffron stigma-like structures proliferated in vitro. Agric Biol Chem 1987; 51: 2395-2400. https://doi.org/10.1080/00021369.1987.10868396

14. Aqil F, Ahmad I. Antibacterial properties of traditionally used Indian medicinal plants. Methods Find Exp. Clin Pharmacol 2007; 29 (2): 79-92. https://doi.org/10.1358/mf.2007.29.2.1075347

15. Rainard PA. Colorimetric microassay for opsonins by reduction of NBT in phagocytosing bovine polymorphs. J Immun Meth 1986; 90: 197-201. https://doi.org/10.1016/0022-1759(86)90076-1

16. Chomczynski P, Sacchi N. Single-step method of RNAisolation by acid guanidinium thiocyanate-phenol-chloroform extraction. Annual biochemistry 1987; 162:156-9. https://doi.org/10.1006/abio.1987.9999

17. Mohd Adzim KR, Che Abdullah AB, Abdul MA. Total antioxidant activity, total phenolic content and radical scavenging activity both flesh and peel of red pitaya, white pitaya and papaya. Int J Pharm Pharm Sci 2012; 4(2):113 122

18. Ma S, Zhou S, Shu B, Zhou J. Pharmacological studies on Crocus glycosides I. Effects on anti-inflammatory and immune function. Zhongcaoyao 1998; 29: 536-539. https://doi.org/10.1016/B978-0-12-411462-3.00033-3

19. Bittar M, de Souza MM, Yunes RA, Lento R., DelleMonache F, Cechinel Filho V. Antinociceptive activity of I3, II8binaringenin, a biflavonoid present in plants of the Guttiferae planta. Med 2000; 66: 84-86. https://doi.org/10.1055/s-0029-1243118

20. Galati EM, Monforte MT, Kirjavainen S, Forestieri AM, Trovato A, Tripodo MM. Biological effects of hesperidin, a citrus flavonoid. (Note I): anti-inflammatory and analgesic activity. Farmaco 1994; 40: 709-712. https://doi.org/10.3390/molecules24030648

21. Ramesh M, Rao YN, Rao AV, Prabhakar MC, Rao CS, Muralidhar N, Reddy BM. Antinociceptive and antiinflammatory activity of a flavonoid isolated from Carallumaattenuata. J Ethnopharmacol 1998; 62:63-66. https://doi.org/10.1016/S0378-8741(98)00048-8

22. Hosseinzadeh H, Khosravan V. Anticonvulsant effects of aqueous and ethanolic extracts of Crocus sativus L. stigmas in mice. Arch. Iran Med 2002a; 5: 44-47.

23. Hosseinzadeh H, Younesi HM. Antinociceptive and antiinflammatory effects of Crocus sativus L. stigma and petal extracts. BMC Pharmacol 2002b; $2: 7$. https://doi.org/10.1186/1471-2210-2-7 
24. Starec M, Waitzov'a D, Elis J. Evaluation of the analgesic effect of RG-tannin using the "hot plate" and "tail flick" method in mice. Cesk Farm 1988; 37:319-321. PMID: 3197132

25. Marinova D, Ribarova F, Atanassova M. Total phenolics and total flavonoids in Bulgarian fruits and vegetables. J Univ Chem Technol Metall 2005; 40: 255-260.

26. Ibrahim MH, Hawa ZEJ. Carbon dioxide fertilization enhanced antioxidant compounds in Malaysian Kacip Fatimah (Labisiapumila Blume). Molecules 2011; 16: 60686081. https://doi.org/10.3390/ijms13010393

27. Ibrahim MH, Jaafar HZE. Enhancement of leaf gas exchange and primary metabolites, up-regulate the production of secondary metabolites of Labisia pumila Blume seedlings under carbon dioxide enrichment. Molecules 2011; (16): 3761-3777. https://doi.org/10.3390/molecules 16053761

28. Ibrahim MH, Jaafar HZE. Photosynthetic capacity, photochemical efficiency and chlorophyll content of three varieties of Labisiapumila Benth. Exposed to open field and greenhouse growing conditions. Acta Physiol. Plant 2011; (33): 2179-2185. https://doi.org/10.1007/s11738-009-048-Y

29. Ibrahim MH, Jaafar HZE. The influence of carbohydrate, protein and phenylanine ammonia lyase on up-regulation of production of secondary metabolites (total phenolics and flavonoid) in Labisiapumila (Blume) Fern-Vill (Kacip Fatimah) under high $\mathrm{CO}_{2}$ and different nitrogen levels. Molecules 2011; (16): 4172-4190. https://doi.org/10.3390/molecules 16054172

30. Ibrahim MH, Jaafar HZE. The relationship of nitrogen and $\mathrm{C} / \mathrm{N}$ on secondary metabolites and antioxidant activities in three varieties of Malaysia Kacip Fatimah (Labisiapumila blume). Molecules 2011; (16): 5514-5526. https://doi.org/10.3390/molecules16075514

31. Ibrahim MH, Jaafar HZE, Haniff MH, Raffi MY. Changes in growth and photosynthetic patterns of oil palm seedling exposed to short term $\mathrm{CO}_{2}$ enrichment in a closed top chamber. Acta Physiol Plant 2010; (32): 305-313. https://doi.org/10.1007/s11738-009-0408-y

32. Ibrahim MH, Jaafar HZE, Rahmat A, Zaharah AR. Effects of nitrogen fertilization on synthesis of primary and secondary metabolites in three varieties of Kacip Fatimah (Labisiapumila blume). Int J Mol Sci 2011; (12): 5238-5254. https://doi.org/10.3390/ijms12085238
33. Arirudran B, Thenmozhi A, Priyadharshini P. Evaluation of preliminary phytochemicals and antioxidant efficacy of Crocus sativus L. Int J Pharm Res Dev 2014; 5(12): 1-8. https://doi.org/10.1016/j.sajb.2015.03.194

34. Mahadeva Rao US, Ahmad BA, Mohd KS. In vitro nitric oxide scavenging and anti inflammatory activities of different solvent extracts of various parts of Musa paradisiaca. Malaysian J Anal Sci 2016; 20(5): 1191 - 1202. https://doi.org/10.17576/mjas-2016-2005-26

35. USMR, Zin T. The effect of Syringin on the expression of TNF- $\alpha$, iNOS, ICAM- 1 and its' mRNA in the heart, brain and kidneys of spontaneously hypertensive rats. Der Pharmacia Lettre 2016; 8(3):53-61.

36. Khalili Rohin MA, Norhaslinda R, Jumli MN, Abd Hadi N, Hussin N, Zahary MN, Syed Ahmad Tajudin Tuan Johari, Mahadeva Rao US, Ahmad Zubaidi A. Latif. Screening of bismillah leaf (Vernonia amygdalina) extraction for antiproliferative activies in human glioblastoma brain cancer cell lines. Research J Pharm, Biol Chemical Sci 2016; 7(2):1084-89.

37. Sundaram SC, Mahadeva Rao US, Simbak N. Regulatory efficacy of scopoletin, a biocoumarin on aortic oxidolipidemic stress through antioxidant potency as well as suppression of mrna expression of inos gene in hypercholesterolemic rats. Der Pharmacia Lettre 2015; 7 (10):57-67

38. Danladi S, Wan-Azemin A, Sani YN, Mohd KS, USMR, Mansor SM, Dharmaraj S. Phytochemical screening, antioxidant potential and cytotoxic activity of Melastomamala bathricum linn from different locations. Int J Pharm Pharm Sci 2015; 7(7): 408-413. https://doi.org/10.1155/2014/614273

39. Atif AB, Zahri MK, Esa AR, Zilfalil BA, USM Rao, S Nordin. Comparative analysis of the antibacterial, antifungal, antiproliferative and cyclic response element (CRE) induced expression of downstream luc gene activities of Monopterusalbus and Channastraitus extracts. J Appl Pharm Sci 2015; 5 (1):42-47. https://doi.org/10.7324/JAPS.2015.50108

40. USMR Kumar Ponnusamy, Naidu JR, Sundaram CS. Modulatory influence of avocado on renal oxidolipidemic stress and MRNA expression of NOS in renal artery studied in nephropathy induced rats. Intl Med J (Japan) 2014; 21(3):353-58 